Prom

\begin{tabular}{|c|}
\hline AUG 07 亿 \\
\hline OSTI \\
\hline
\end{tabular}

High-Precision Geologic Mapping

to Evaluate the Potential for

Seismic Surface Rupture at TA-55,

Los Alamos National Laboratory

Jamie N. Gardner

Alexis Lavine

David Vaniman

Giday WoldeGabriel 


\section{DISCLAIMER}

This report was prepared as an account of work sponsored by an agency of the United States Government. Neither the United States Government nor any agency thereof, nor any of their employees, makes any warranty, express or implied, or assumes any legal liability or responsibility for the accuracy, completeness, or usefulness of any information, apparatus, product, or process disclosed, or represents that its use would not infringe privately owned rights. Reference herein to any specific commercial product, process, or service by trade name, trademark, manufacturer, or otherwise does not necessarily constitute or imply its endorsement, recommendation, or favoring by the United States Government or any agency thereof. The views and opinions of authors expressed herein do not necessarily state or reflect those of the United States Government or any agency thereof. 


\section{DISCLAIMER}

Portions of this document may be illegible electronic image products. Images are produced from the best available original document. 


\title{
HIGH-PRECISION GEOLOGIC MAPPING TO EVALUATE THE POTENTIAL FOR SEISMIC SURFACE RUPTURE AT TA-55, LOS ALAMOS NATIONAL LABORATORY
}

\author{
by \\ Jamie N. Gardner, Alexis Lavine, David Vaniman, and Giday WoldeGabriel
}

\begin{abstract}
Los Alamos National Laboratory lies at the western boundary of the Rio Grande Rift, a major tectonic feature of the North American Continent. The rift boundary is locally defined by the Pajarito Fault System, which includes the Pajarito, Guaje Mountain, and Rendija Canyon Faults. These faults exhibit prominent displacement of the 1.2-million year old Tshirege Member of the Bandelier Tuff to the north and to the west of the Laboratory; however, if, and how, any of these faults impinge upon the Laboratory proper has been, to this point, a matter of some conjecture. The north-south striking Rendija Canyon Fault has been previously mapped from northern Los Alamos County to Los Alamos Canyon, but portions farther south and the southern termination of the fault are not understood. Because sensitive facilities at TA-55 lie south of the mapped trace of the Rendija Canyon Fault, there has been concern that the fault could pass through TA-55. The fault is potentially seismogenic, has up to 120 feet of down-to-the-west displacement in the last 1.2 million years, and experienced most recent movements at either $8 \mathrm{ka}$ or $22 \mathrm{ka}$.
\end{abstract}

In this report we document results of high-precision geologic mapping in the vicinity of TA-55 that has been done to identify parts of the southern portion of the Rendija Canyon Fault, or any other faults, with the potential for seismic surface rupture. To assess the potential for surface rupture at TA-55, an area of approximately 3 square miles that includes the Los Alamos County Landfill and Twomile, Mortandad, and Sandia Canyons has been mapped in detail. Map units are mostly cooling or flow units within the Tshirege Member (1.2 Ma) of the Bandelier Tuff. Stratigraphic markers that are useful for determining offsets in the map area include a distinct welding break at or near the cooling Unit 2-Unit 3 contact, and the Unit 3-Unit 4 contact. At the County Landfill the contact between the Tshirege Member of the Bandelier Tuff and overlying Quaternary alluvium has also been mapped. Our mapping indicates that there is no faulting in the near-surface directly below TA-55, and that the closest fault is about 1500 feet west of the Plutonium Facility. Faulting is more abundant on the western edge of the 
map area, west of TA-48 in uppermost Mortandad Canyon, upper Sandia Canyon, and at the County Landfill. Measured vertical offsets on the faults range from 1 to 8 feet on mapped Bandelier Tuff contacts. Faulting exposed at the Los Alamos County Landfill has deformed a zone over 1000 feet wide, and has a net vertical down-to-the-west displacement of at least 15 feet in the Bandelier Tuff. Individual faults at the landfill have from less than 1 foot to greater than 15 feet of vertical offset on the Bandelier Tuff. Most faults in the landfill trend N-S, N20W, or N45E. Results of our mapping indicate that the Rendija Canyon Fault does not continue directly south to TA-55. At present, we have insufficient data to connect faulting we have mapped to areas of known faulting to the north or south of the study area.

\section{INTRODUCTION}

Los Alamos National Laboratory lies at the western boundary of the Rio Grande Rift, a major tectonic feature of the North American Continent. The Rio Grande Rift is expressed on the surface of the Earth as a series of elongate north-south trending basins that run from central Colorado, through the eentral parts of New Mexico, into northern Mexico. The rift is the site of east-west tectonic extension, which - causes the Earth's crust along the rift to stretch, thin, and break. The rift boundary is locally defined by the Pajarito Fault System, which includes the Pajarito, Guaje Mountain, and Rendija Canyon Faults (Figure 1). These faults exhibit prominent displacement of the 1.2-million year old Tshirege Member of the Bandelier Tuff to the north and to the west of the Laboratory (for example, Gardner and House, 1987). Each of the three major faults of the Pajarito Fault System exhibits evidence of at least one large movement, or, in one case, probable movement, in the Holocene Epoch (last 11,000 years), which in turn indicates that all are potentially seismogenic (Gardner et al., 1990; Wong et al., 1995; Kelson et al., 1996). As detailed mapping progresses, numerous smaller faults are being recognized, some of these faults probably represent ruptures subsidiary to the major faults, and some are probably unrelated faults.

This study addresses issues of site-specific seismic surface rupture potential at TA-55. Wong et al. (1995) and Kelson et al. (1996) provided evidence that the Rendija Canyon Fault is potentially seismogenic, and, because TA-55 lies south of, and on strike with, mapped traces of the fault, there have been concerns that the fault may run through the site. A figure (Figure 1-1 of Wong et al., 1995) that appeared in the Seismic Hazards Evaluation study by Woodward-Clyde Federal Services (WCFS) and has been reproduced by Kelson et al. (1996), Wong et al. (1996), and Olig et al. (1996), appeared to fortify these concerns. This figure shows an inferred southern projection of the Rendija Canyon Fault running through TA-55. The inferred southern projection of the fault was based largely on aerial photography studies in this portion of the Laboratory; Wong et al. (1995) did no mapping around TA-55 for the hazards study. In addition, trenching and field studies at TA-67 (see Reneau and Raymond, 


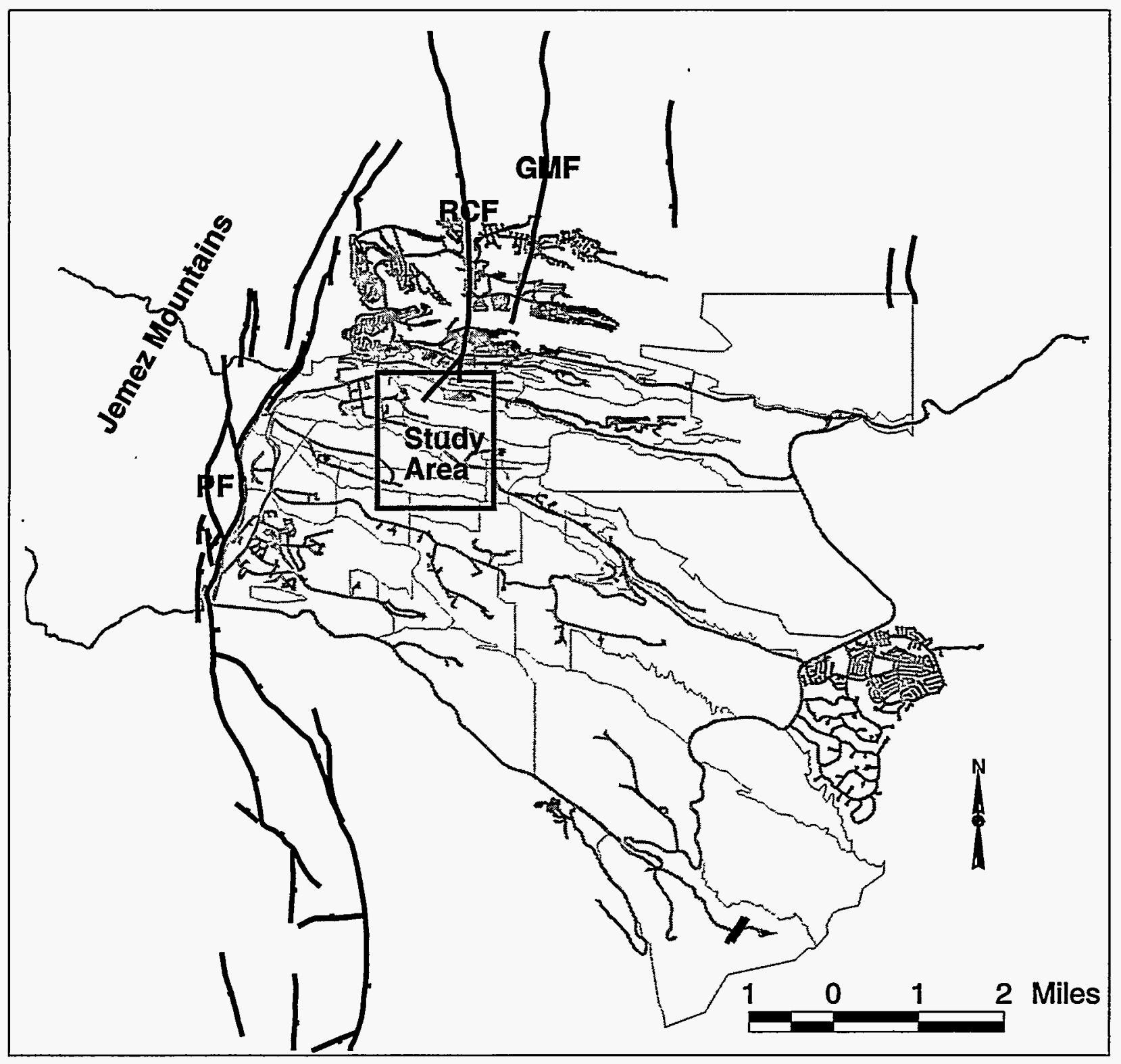

Figure 1. Map showing the study area and previously mapped faults around Los Alamos National Laboratory (LANL): PF = Pajarito Fault, RCF = Rendija Canyon Fault, GMF = Guaje Mountain Fault. The gray shaded area is LANL. Technical areas are outlined.

1995, for summaries), south of TA-55, indicated the presence of a fault zone which Wong et al. (1995) showed in the aforementioned figure as the southern end of the Rendija Canyon Fault. Early work by Dames and Moore (1972) in trenches at TA-55 has proved to be inconclusive, and an earlier report by Wong et al. (1991) stated that data were insufficient to adequately locate the fault south of Los Alamos Canyon. Other workers (Dransfield and Gardner, 1985), using a variety of data, had previously interpreted the southern projection of the Rendija Canyon Fault to be in the pre-Bandelier Tuff subsurface west of TA-55; they actually placed the fault's southern projection close to TA-48, but the resolution allowed by the data available then was poor. Based on linear topographic features and fracture studies, Vaniman and Wohletz (1990) also inferred the fault to be close to TA-48. Another WCFS study done 
for the Laboratory (Kolbe et al., 1995), shows only "aerial photography lineaments" in the same location as the southern fault projection of Dransfield and Gardner (1985) and Vaniman and Wohletz (1990). It is important to note that the Kolbe et al. (1995) study cites the Wong et al. (1995) study, in its draft stages, as the source of these aerial photography data, and the Kolbe et al. (1995) study shows the southern terminus of the Rendija Canyon Fault at the County Landfill.

Because previous studies have proven inconclusive in determining the location and amount of faulting south of Los Alamos Canyon in the vicinity of TA-55, we embarked on a program of high-precision geologic mapping to identify even very small faults in the Bandelier Tuff. The purpose of this project is to identify faults capable of surface rupture in the vicinity of TA-55 that cut the Tshirege Member of the Bandelier Tuff (1.2 Ma) with greater than approximately 1 foot of vertical displacement, and to ultimately determine if and how faults so identified relate to areas of known faulting to the north and south of TA-55. It must be stressed, however, that just because a fault is identified to cut the Bandelier Tuff, it is not necessarily potentially "active," or "capable" (in the definitions of the Code of Federal Regulations, 10 CFR 100-A). This is a report on work in progress, so not all objectives have been achieved at the time this report was prepared. Consequently, the study area (Figure 1 and Figure 2) covered by this report is approximately 3 square miles, which include the Los Alamos County Landfill and portions of Twomile, Mortandad, and Sandia Canyons (Figure 2). Although mapping in the immediate vicinity of TA-55 is complete, future work will determine where splays of the southern portion of the Rendija Canyon Fault are located, and how newly identified faults relate to previously mapped faults north and south of the present study area.

\section{METHODS}

Concerns over potential seismic surface ruptures at sensitive facilities at Los Alamos National Laboratory motivated us to develop a unique approach to geologic mapping that enables recognition of vertical fault displacements so small that they would be overlooked and unmapped by conventional geologic mapping techniques (see, for example, Reneau et al., 1995). Our approach involves actual surveying of points on geologic features in the field, using a Geodimeter Total Station with an on-board computer, and detailed computer-aided and field analyses of anomalies in the elevations of the points surveyed on a given geologic surface.

As part of the Environmental Restoration Program, the Facility for Information Management Analysis and Display (FIMAD) was established at the Laboratory in 1991 to serve as a geographic information system (GIS) for environmental data. With the development of a highly accurate digital elevation model for the Laboratory as part of this GIS, FIMAD ran a series of quality assurance checks on established survey monuments, or benchmarks, around the Laboratory. Large inaccuracies were revealed, 


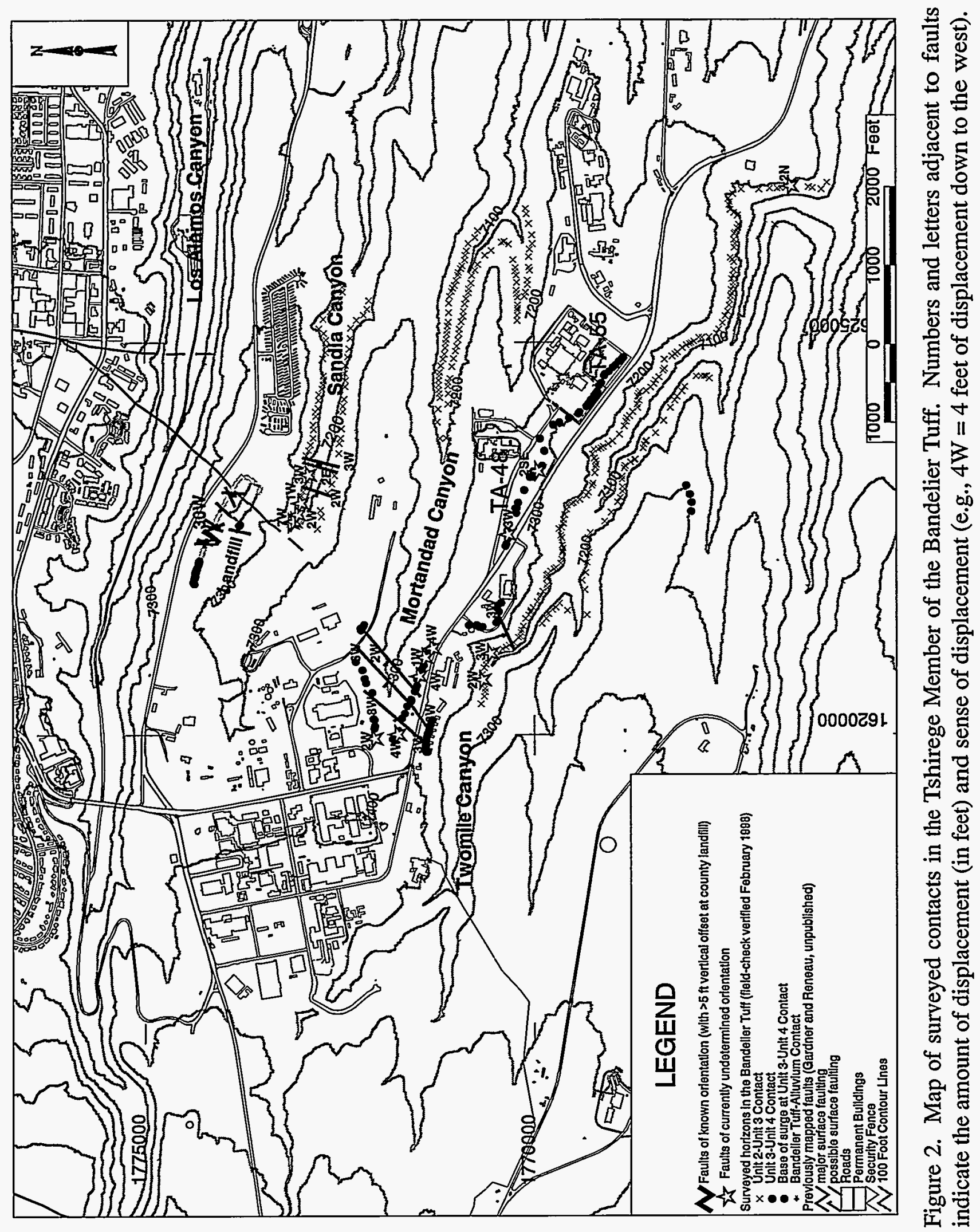


and in 1992 a new Lab-wide control network of "good" survey monuments was established. Benchmarks of this control network of monuments in the vicinity of TA-55 form the framework for locating our surveyed points in absolute three-dimensional space.

Instrument setups are done by triangulation on benchmarks which enables location of the Geodimeter Total Station in coordinates of the New Mexico Central Zone Plane Coordinate System, 1983 North American Datum. These data are obtained in real-time in the field and allow calculations to evaluate the quality of the setup and instrument location. Typical precision of an instrument setup is better than 0.05 feet in the $\mathrm{X}$ and $\mathrm{Y}$ directions (easting and northing), and better than 0.02 feet in the $\mathrm{Z}$ direction (elevation). Precision of surveyed points is tested at the beginning and end of every instrument setup by shooting points of known coordinates as checks; invariably, the precision of surveyed points is better than the precision of the instrument setup.

Closure on survey monuments at the extremities of our study area suggest a cumulative error in absolute three-dimensional space, assuming the benchmarks are all correct, of less than 3 feet in northing and easting and less than approximately 0.25 feet in elevation over 10,000 surveyed feet. In contrast to procedures of typical surveys, we do not make repeated corrections for cumulative errors; instead, our data form an internally consistent set. While our objectives require greater precision than is provided by routine geologic mapping, we do not require the precision and accuracy of routine survey work. For the purposes of this project it is sufficient to locate small faults within a few feet in absolute space with reference to established benchmarks. Furthermore, with the integration of our data through FIMAD, it is possible to accurately plot our surveyed points on high-resolution aerial orthophotographs on which one can identify individual rocks, trees, and other detailed features; thus, if needed, each surveyed point can be accurately relocated in the field.

Field data are analyzed in profiles, three-dimensional surface diagrams, and maps which are constructed with several software packages (Surfer, Excel, Canvas, and ArcView GIS). The different software packages are capable of generating profiles of the same data at dramatically different scales, which enables exaggeration, and therefore identification, of even subtle anomalies. Surveyed points surrounding -anomalies are plotted on aerial orthophotographs, and the anomalies are evaluated in the field to determine if, in fact, they indicate faulting.

\section{GEOLOGY}

Most of the units and stratigraphic markers we are mapping are cooling unit contacts or individual pyroclastic surges within the Tshirege Member of the Bandelier Tuff. The Tshirege Member was erupted at 1.22 Ma (Izett and Obradovich, 1994) as a series of hot pyroclastic flows. Although the 
pyroclastic flows were erupted in fairly rapid succession, sufficient time passed between major eruptive pulses so that packages of the resultant ignimbrite deposits cooled as discrete units. The petrography and nomenclature for these units are described in detail by Broxton and Reneau (1995). Here we briefly describe salient field characteristics of the features we are mapping.

In the immediate vicinity of TA-55, there are three main features mapped: the contact of cooling Units 2 and 3, the contact of cooling Units 3 and 4, and a pyroclastic surge deposit that commonly lies between cooling Units 3 and 4. All of these features exhibit a regional strike and dip of about N33E, 5 to 7 degrees SE. Additionally, the contact between Bandelier Tuff and overlying Quaternary alluvium was mapped at the Los Alamos County Landfill.

\section{Unit 2}

Unit 2 is recognized in the field as a prominent cliff-forming unit and the most strongly welded unit of the Tshirege Member in the central parts of the Laboratory. In fact, the unit is so densely welded that it forms impassable cliffs near the bottoms of some canyons around TA-55 (for example, Twomile Canyon). Accidental lithic fragments are rare $(<1 \%)$, and the welded tuff is moderately porphyritic $(15-20 \%$ phenocrysts). Pumices tend to be relatively sparse (5-10\%), but can be difficult to distinguish because of the densely welded nature of the unit.

\section{Unit 3}

The boundary between Unit 2 and the overlying Unit 3 is marked by an abrupt change in welding characteristics. The transition from the densely welded tuffs of Unit 2 to the completely nonwelded tuffs of lower Unit 3 occurs over a stratigraphic interval of less than 3 feet, and Broxton and Reneau (1995) define the base of Unit 3 as the base of these nonwelded tuffs. Unit 3 is more pumice rich (about $30 \%$ ) than Unit 2, and contains relatively abundant accidental lithic fragments. In contrast to Unit 2, Unit 3 is more porphyritic, with about $30 \%$ phenocrysts.

\section{Pyroclastic Surge and Unit 4}

In the immediate vicinity of TA-55 Unit 4 is a thin ignimbrite, with a basal pyroclastic surge, that pinches out to the east. Around TA-55, the surge is a crystal-rich deposit which ranges in thickness from 0.3 to 0.5 feet, and exhibits low-angle cross beds and plane beds. The ignimbrite is relatively pumice and crystal poor ( $<10 \%$ phenocrysts, $<5 \%$ pumice), and is nonwelded to partly welded.

\section{Quaternary Alluvial Deposits}

At the Los Alamos County Landfill, silts, sands, gravels, soils, and reworked pyroclastic deposits overlie the Bandelier Tuff. These deposits lie on an erosional surface on either Unit 3 or Unit 4 of the Bandelier Tuff. Alluvial gravels contain abundant pumice and dacite clasts that were deposited by a 
fluvial system that preceded incision of Los Alamos Canyon. Wong et al. (1995) interpreted these deposits as being at least several hundred thousand years old. Analyses of pumices contained in these deposits provides a maximum age of 1.16 to $1.21 \mathrm{Ma}$ (Reneau and McDonald, 1996).

\section{RESULTS}

Mapping in the vicinity of TA-55 includes the sharp welding transition near the Unit 2-Unit 3 contact in Twomile, Mortandad, and Sandia Canyons, the Unit 3-Unit 4 contact in Twomile and Mortandad Canyons and in the County Landfill, and the contact between the Bandelier Tuff and overlying alluvial deposits at the County Landfill (Figure 2). The Unit 2-Unit 3 welding horizon is the most extensive stratigraphic marker around TA-55. The Unit 3-Unit 4 contact is primarily found to the west of TA-55, and Unit 4 pinches out to the east just south of TA-55 along Pajarito Road.

The Unit 2-Unit 3 horizon exhibits no offsets in a north-south swath, about 2000 feet wide centered on TA-55, from Sandia Canyon on the north to Twomile Canyon on the south. The Unit 3-Unit 4 contact is offset approximately 2 feet (down-to-the-southeast), 1500 feet to the west of the Plutonium Facility at TA-55 (Figure 2), but this small fault dies out to the south and is not observed on the Unit 2-Unit 3 contact in Twomile Canyon. Offsets on both contacts become more abundant to the west of TA-48 in Twomile and Mortandad Canyons. Offsets in the Unit 2-Unit 3 horizon become more abundant just south of the County Landfill in Sandia Canyon. Offsets observed in the Unit 2-Unit 3 horizon range from 0.5 to 6 feet; offsets observed on the Unit 3-Unit 4 contact range from 0.5 to 8 feet. Because many of the fault planes are not exposed, the azimuth and dip of some faults are yet undetermined; however, faults for which the orientation has been determined generally strike northeast or north and are nearvertical.

An increase in faulting to the west of TA-48 (Figure 2) is very apparent in the three-dimensional surface diagrams (Figures 3 and 4). These diagrams are created in Surfer using kriging to interpolate and contour the surfaces of cooling units based on the surveyed points. Because the Bandelier Tuff dips approximately 7 degrees to the southeast, the contacts can be represented by a gently-dipping planar surface in the absence of faulting. Down-to-the-east faulting would result in a steepening of the dip of the surface, and down-to-the-west faulting would result in apparent flattening of the surface. Flattening of the Unit 2-Unit 3 horizon can be seen in the western portions of Twomile and Sandia Canyons, and flattening of the Unit 3-Unit 4 contact can be seen in the western portion of Mortandad Canyon.

Excellent exposures in the Los Alamos County Landfill allowed us to determine the orientation of many of the faults and characterize a broad zone of faulting. Forty-four faults were mapped at the 


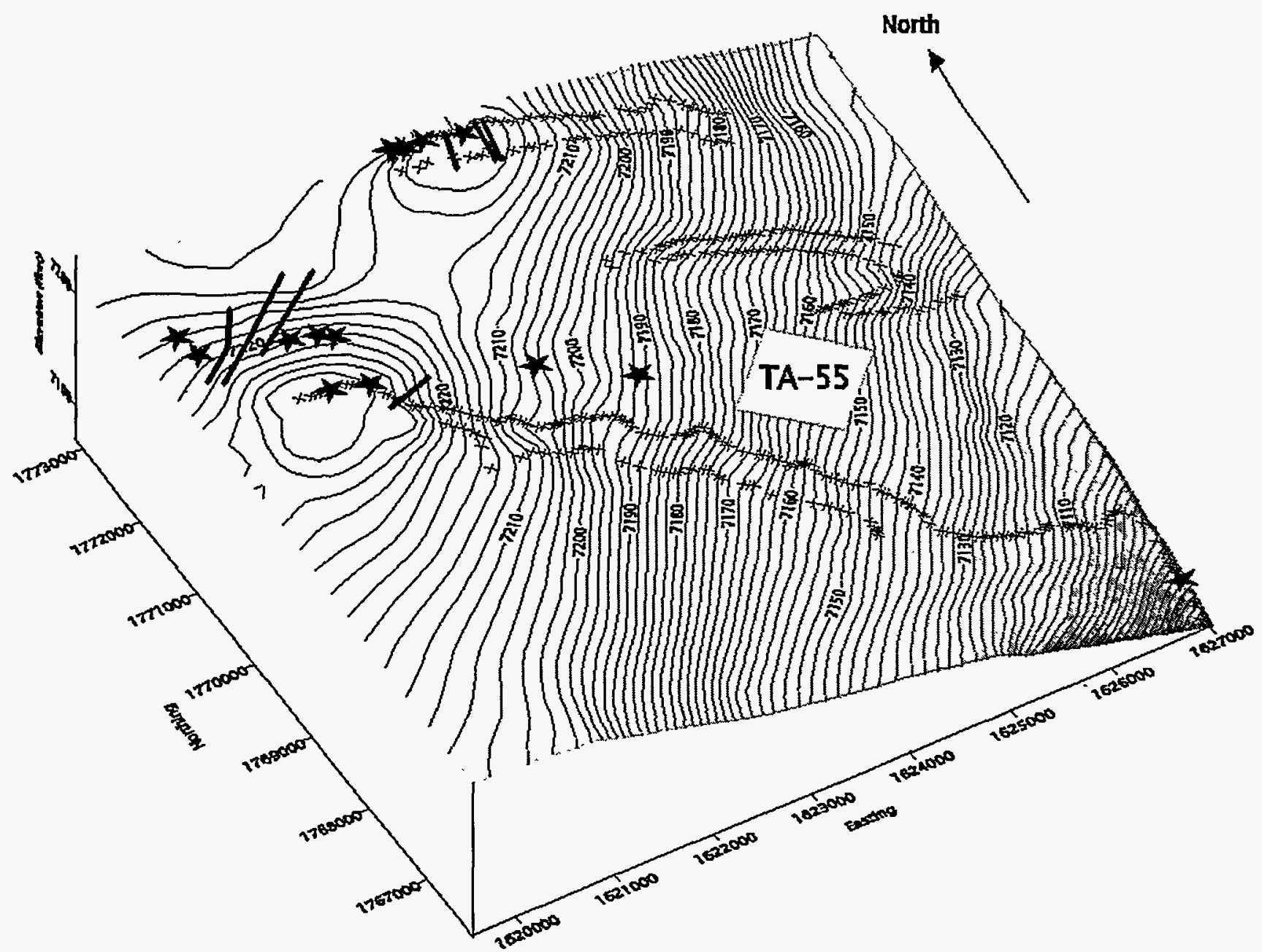

Figure 3. Top surface of cooling Unit 2 of the Tshirege Member of the Bandelier Tuff, as modeled by the software Surfer. Surface is based on kriging of data points and is shown with 2-foot contours. Surveyed points on the Unit 2-Unit 3 contact are shown by black "Xs." In areas with no deformation, the Bandelier Tuff dips approximately 7 degrees toward the southeast. Areas of flattening represent down-to-the-west faulting. In areas of sparse data, the software creates artificial details that should be ignored. Black stars are faults of currently undetermined orientation. Black lines are faults.

landfill, with vertical offsets ranging from less than 1 foot to greater than 15 feet on the Bandelier TuffQuaternary alluvium contact. Faulting at the landfill is part of a zone of faulting at least 1000 feet wide, which includes several grabens, and has a net vertical down-to-the-west displacement of at least 15 feet in the Bandelier Tuff. Most faults in the landfill trend N-S, N20W, or N45E. Many of the faults exposed in the landfill cut through Quaternary alluvial deposits. However, because the sedimentary package is incomplete as a result of erosion and human disturbances, these sediments may not be of great help in the dating of paleo-earthquakes. We have not mapped the sediments in detail; however, it appears that the sedimentary sequence is similar to that logged and described by Wong et al. (1995). At present we have not been able to connect faults mapped at the landfill with mapped faults to the north or south. Nevertheless, as mapping continues in Los Alamos Canyon and to the south of the landfill, it should be possible to connect many of these faults and to determine the structural relations, or lack thereof, between these faults and the Rendija Canyon and Pajarito Faults. 


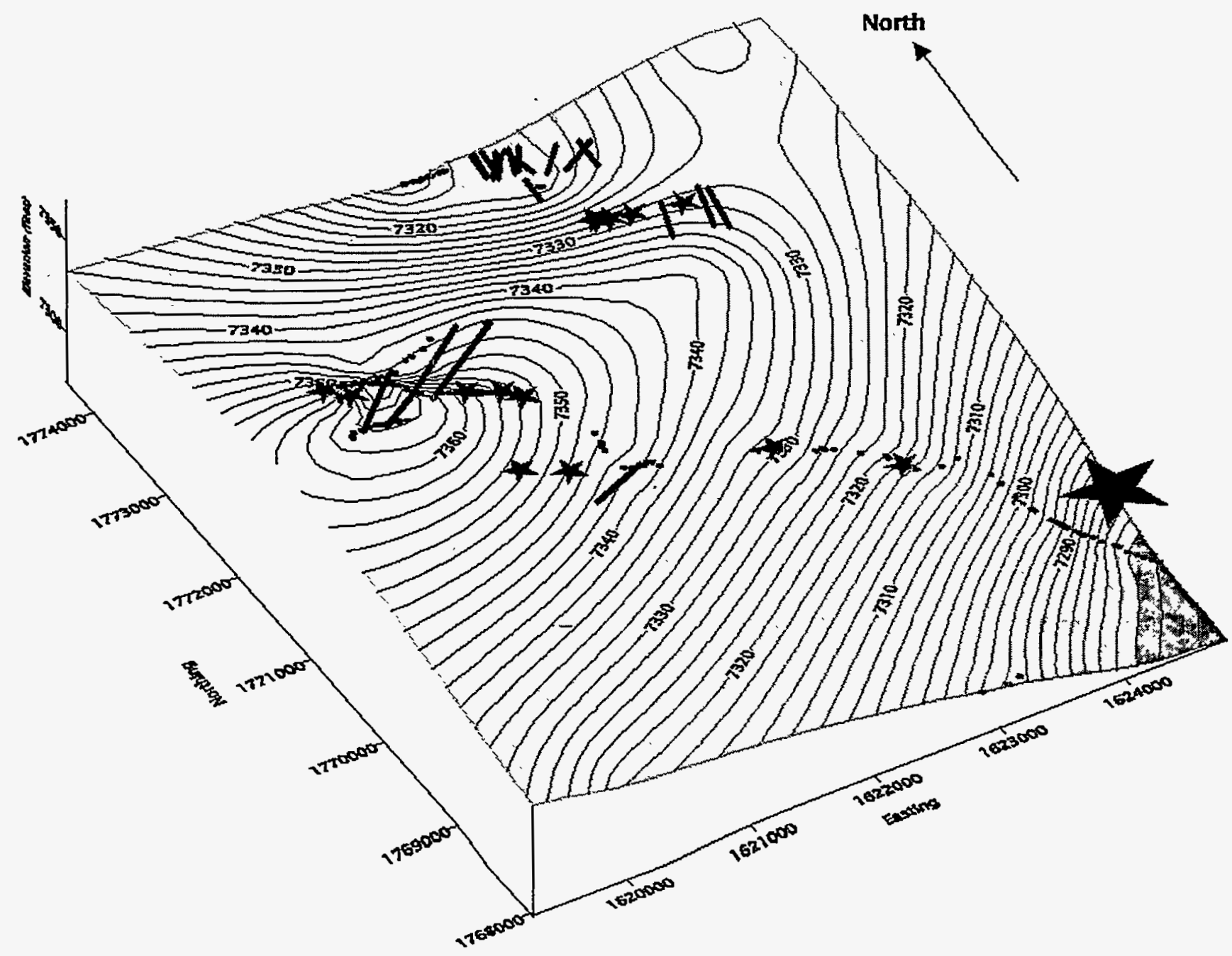

Figure 4. Top surface of cooling Unit 3 of the Tshirege Member of the Bandelier Tuff, as modeled by the software Surfer. Surface is based on kriging of data points and is shown with 2 -foot contours. Data points on the Unit 3-Unit 4 contact are shown by black dots. In areas with no deformation, the Bandelier Tuff dips approximately 7 degrees toward the southeast. Large black star shows location of TA-55. Small black stars are faults of currently undetermined orientation. Black lines are faults.

Most of the faults that we have identified are small, probably too small to be individually seismogenic. Instead, they are likely subsidiary ruptures that occurred during paleoseismic events on the Pajarito, Rendija Canyon, and/or Guaje Mountain Faults, the three local faults that are considered to be potentially seismogenic. Moreover, for most of the newly identified faults we can demonstrate only small displacements on the Bandelier Tuff.

\section{CONCLUSIONS}

(1) No faults have been recognized in the Bandelier Tuff (1.22 Ma) in the vicinity of TA-55 in a highprecision geologic survey. The closest faulting to TA-55 is a down-to-the-southeast fault with 2 feet of vertical offset within the Bandelier Tuff that is approximately 1500 feet west of the Plutonium Facility. 
(2) Our data indicate that faults previously logged to the south of TA-55 on Pajarito Mesa (Kolbe et al., 1994; Reneau et al., 1995) do not connect with the Rendija Canyon Fault to the north.

(3) The zone of intense faulting mapped at the Los Alamos County Landfill may represent a splay of the Rendija Canyon Fault, but future mapping in Los Alamos Canyon is necessary to confirm this.

\section{ACKNOWLEDGMENTS}

This work is part of Los Alamos National Laboratory's program to identify and mitigate potential seismic hazards. Peg Snow and Emily Kluk assisted with some of the fieldwork. Steve Reneau, who helped pioneer the high-precision mapping methods, provided discussions of the results and a review of the manuscript. Lanny Piotrowski and Margaret Burgess were very helpful in putting the manuscript together for printing. Dave Post, Scott Gibbs, T. J. Trapp, Doug Volkman, Larry Goen, Jim Holt, Jeff Kimball, and the Defense Nuclear Facilities Safety Board provided support of various kinds for the project.

\section{REFERENCES}

Broxton, D. E. and Reneau, S. L., 1995, Stratigraphic Nomenclature of the Bandelier Tuff for the Environmental Restoration Project at Los Alamos National Laboratory; Los Alamos National Laboratory report LA-13010-MS.

Dames and Moore, 1972, Report of geologic foundation, hydrologic and seismic investigation, Plutonium Processing Facility, Los Alamos Scientific Laboratory; unpublished consulting report prepared for the U. S. Atomic Energy Commission by Dames and Moore, Inc., Los Angeles, CA.

Dransfield, B. J., and Gardner, J. N., 1985, Subsurface geology of the Pajarito Plateau, Espanola Basin, New Mexico; Los Alamos National Laboratory report LA-10455-MS.

Gardner, J. N., and House, L., 1987, Seismic Hazards Investigations at Los Alamos National Laboratory, 1984 to 1985; Los Alamos National Laboratory report LA-11072-MS.

Gardner, J. N., Baldridge, W. S., Gribble, R., Manley, K., Tanaka, K., Geissman, J. W., Gonzalez, M., and Baron, G., 1990, Results from Seismic Hazards Trench \#1 (SHT-1), Los Alamos Seismic Hazards Investigations; Los Alamos National Laboratory unpublished report EES1-SH90-19. 
Izett, G. A., and Obradovich, J. D., 1994, 40-Ar/39-Ar age constraints for the Jaramillo normal subchron and the Matuyama-Brunhes geomagnetic boundary; Journal of Geophysical Research 99, pp. 2925-2934.

Kelson, K. I., Hemphill-Haley, M. A., Olig, S. S., Simpson, G. D., Gardner, J. N., Reneau, S. L., Kolbe, T. R., Forman, S. L., and Wong, I. G., 1996, Late-Pleistocene and Possibly Holocene Displacement along the Rendija Canyon Fault, Los Alamos County, New Mexico: New Mexico Geological Society Guidebook, 47 ${ }^{\text {th }}$ Field Conference, Jemez Mountains Region, pp. 153-160.

Kolbe, T., Sawyer, J., Gorton, A., Olig, S., Simpson, D., Fenton, C., Reneau, S., Carney, J., Bott, J., and Wong, I., 1994, Evaluation of the potential for surface faulting at the proposed Mixed Waste Disposal Facility, TA-67; unpublished consulting report prepared for the Los Alamos National Laboratory by Woodward-Clyde Federal Services, Oakland, CA.

Kolbe, T., Sawyer, T., Springer, J., Olig, S., Reneau, S., Hemphill-Haley, M., and Wong, I., 1995, Evaluation of the potential for surface faulting at TA-63; unpublished consulting report prepared for Los Alamos National Laboratory by Woodward-Clyde Federal Services, Oakland, CA.

Olig, S., Kelson, K. I., Gardner, J. N., Reneau, S. L, and Hemphill-Haley, M., 1996, Earthquake Potential of the Pajarito Fault System, New Mexico; New Mexico Geological Society Guidebook, $47^{\text {th }}$ Field Conference, Jemez Mountains Region, pp. 143-151.

Reneau, S. L., Kolbe, T. R., Simpson, D. T., Carney, J. S., Gardner, J. N., Olig, S. S., and Vaniman, D. T., 1995, Surficial materials and structure at Pajarito Mesa; in Geological site characterization for the proposed Mixed Waste Disposal Facility, Los Alamos National Laboratory, S. L. Reneau and R. Raymond, eds., Los Alamos National Laboratory report LA-13089-MS.

Reneau, S. L., and Raymond, R., (eds.), 1995, Geological Site Characterization for the Proposed Mixed Waste Disposal Facility, Los Alamos National Laboratory; Los Alamos National Laboratory report LA-13089-MS.

Reneau, S. L., and McDonald, E. V., 1996, Landscape history and processes on the Pajarito Plateau, northern New Mexico; unpublished guidebook prepared for the Rocky Mountain Cell of the Friends of the Pleistocene, Los Alamos National Laboratory report LA-UR-96-3035.

Vaniman, D., and Wohletz, K., 1990, Results of geological mapping and fracture studies: TA-55 area; unpublished memo report, Los Alamos National Laboratory, EES1-SH90-17. 
Wong, I., Kelson, K., and Hemphill-Haley, M., 1991, Evaluation of the potential for surface rupture; unpublished consulting report prepared for Los Alamos National Laboratory by WoodwardClyde Consultants, Oakland, CA.

Wong, I., Kelson, K., Olig, S., Kolbe, T., Hemphill-Haley, M., Bott, J., Green, R., Kanakari, H., Sawyer, J., Silva, W., Stark, C., Haraden, C., Fenton, C., Unruh, J., Gardner, J., Reneau, S., and House, L., 1995, Seismic hazards evaluation of the Los Alamos National Laboratory; unpublished consulting report prepared for Los Alamos National Laboratory by Woodward-Clyde Federal Services, Oakland, CA.

Wong, I., Kelson, K., Olig, S., Bott, J., Green, R., Kolbe, T., Hemphill-Haley, M., Gardner, J., Reneau, S., and Silva, W., 1996, Earthquake Potential and Ground Shaking Hazard at the Los Alamos National Laboratory, New Mexico: New Mexico Geological Society Guidebook, 47 ${ }^{\text {th }}$ Field Conference, Jemez Mountains Region, pp. 135-142. 